\title{
Influencia de la adición, en diferentes proporciones, de rocas silíceas opalinas al cemento portland
}

\section{Effect of addition of opaline siliceous rocks at different proportions to portland cement}

\author{
M. P. DE LUXAN, M. I. SANCHEZ DE ROJAS, M. FRIAS, IETCC/CSIC \\ J. SAAVEDRA, Instituto de Recursos Naturales y Agrobiologia/CSIC \\ M. T. MARTIN PATINO, Universidad Autónoma de Madrid \\ F. MADRUGA, Junta de Castilla y León

\section{RESUMEN}

En este trabajo se estudia la influencia de la presencia de rocas siliceas opalinas, procedentes de las provincias de Salamanca, Zamora y Avila, en las propiedades de los cementos mixtos fabricados con cemento portland y proporciones variabies de estas rocas utilizadas como adiciones activas.

La caracterización de estos materiales y el estudio de las propiedades de los cementos preparados revelan la capacidad puzolánica de las rocas opalinas, y su singularidad respecto a otras puzolanas naturales, asi como su posibilidad de empleo en la fabricación de cementos con adiciones.

\section{SUMMARY}

The present work studied the effect of the presence of opaline siliceous rocks from the Provinces of Salamaca, Zamora and Avila (Spain) on the properties of mixed cements composed of portland cement and variable proportions of the rock used as active addition.

Characterization of the materials and study of the properties of the cements prepared point to the pozzolanic capacity of these opaline rocks and their singularity compared with other natural pozzolans together with the possibility of using them in the manufacture of cements with additions.

\section{INTRODUCCION}

Las rocas opalinas, de cuyo estudio trata este trabajo, tienen origen sedimentario y datan de la edad Paleocena, terciario más inferior.

Los terrenos donde se localizan alcanzan localmente espesores de varias decenas de metros; son de tipo continental y están sometidos a estaciones alternantes, seca y húmeda, cuyo resultado es el desarrolio de una vegetación intensa de tipo herbáceo o arbustos en el periodo húmedo, que muere y se degrada en la estación seca, dando lugar a un descenso del $\mathrm{pH}$, que ocasiona la precipitación de la sílice.

La sílice, así formada, contiene todos los tránsitos entre amorfa (ópalo A) y la más o menos cristalizada (ópalo CT) como cristobalita/tridimita desordenadas. Todas estas especies metaestables son apreciablemente reactivas (1).

\section{INTRODUCTION}

The opaline rocks studied in the present work are of sedimentary origin and Paleocene or Lower Tertiary in age. The terrains in which they are found reach local thicknesses of several tens of metres; they are continental in nature and are subjected to alternating humid and dry seasons, resulting in the development of an intense herbaceous or bushy vegetation in the wet season which dies and is degraded in the dry season, giving rise to a decrease in $\mathrm{pH}$ which in turn leads to the precipitation of silica.

The silica thus formed contains all the transitions between the amorphous (opal A) and the more or less crystallized forms (opal $C T$ ), such as disordered cristobalite/tridimite. All these metastable species are quite reactive (1). Such reactivity is the leitmotif behind the 
Es en esta reactividad donde la que se fundamentan las investigaciones llevadas a cabo con estos materiales, en las que se plantea su utilización como adiciones activas en el cemento. Fueron iniciadas en 1981 conjuntamente y en coordinación en distintos Centros y que es base de un Proyecto subvencionado por la Comisión Asesora de Investigación Científica y Técnica (CAICYT).

Primeramente, se localizaron yacimientos de rocas opalinas en las provincias de Salamanca, Zamora y Avila, en los que realizaron amplios muestreos.

Las muestras se caracterizaron mediante análisis químico y mineralógico, así como con pruebas que ponían de relieve su capacidad puzolánica, para obtener una catalogación previa.

En general, se trata de materiales con un alto contenido de componentes ácidos $\left(\mathrm{SiO}_{2}+\right.$ $\mathrm{Al}_{2} \mathrm{O}_{3}+\mathrm{Fe}_{2} \mathrm{O}_{3}$ ), superior al $90 \%$ y con una concentración en $\mathrm{SO}_{3}$ inferior al 0,1\% (2) (3).

Los componentes cristalinos, identificados en lámina delgada por microscopía óptica y difracción de rayos $X$ (Fig. 1), son principalmente cuarzo $(\mathrm{Q})$, caolinita $(\mathrm{K})$, ópalo - CT (Cr) y micas (M) (2) (3) (4).

Se observa una gran uniformidad en los materiales, incluso entre aquellos que pertenecen a yacimientos de distintas zonas geográficas. En la figura 1 se recogen los difractogramas de seis muestras pertenecientes a las tres provincias mencionadas.

Para el estudio de la actividad puzolánica de un material se han desarrollado gran cantidad de métodos, que establecen valoraciones que se basan en la observación de distintas propiedades de las muestras (5).

La valoración de la actividad puzolánica de las rocas opalinas se llevó a cabo mediante ensayos sobre el material con hidróxido cálcico.

El primero es un ensayo acelerado de actividad resistente realizado sobre probetas de mortero del material con cal (6), que permite comprobar la capacidad de las rocas opalinas como puzolanas, así como establecer una clasificación entre las muestras (2).

El ensayo por vía química proporciona datos acerca de la velocidad de reacción material hidróxido cálcico, que resulta ser similar a otros productos con caracteristicas puzolánicas reconocidas (3). research carried out on these rocks, which have been proposed for use as active additions for cement. The studies were started in 1981 in a cooperative effort among different Research Centres and have become the basis of a Project financed by the Commission for the Assessment of Scientic and Technical Research (CAICYT).

In preliminary studies, the deposits of opaline rock in the Provinces of Salamanca, Zamora and Avila were located and large-scale samplings were carried out.

The samples were characterized by chemical and mineralogical analysis and by tests to reveal their pozzolanic capacity with a view to obtaining a preliminary catalogue.

In general, the materials have high contents in acid components $\left(\mathrm{SiO}_{2}+\mathrm{Al}_{2} \mathrm{O}_{3}+\mathrm{Fe}_{2} \mathrm{O}_{3}\right)$ higher than $90 \%$ with a concentration of $\mathrm{SO}_{3}$ of less than $0.1 \%$ (2) (3).

The crystalline components, identified in thin sections by optical microscopy and X-ray diffraction (Fig 1), are mainly quartz (Q), Kaolinite (K), opal-CT (Cr) and micas (M) (2) (3) (4).

Great uniformity is observed in the materials, even among those from different geographical zones. Figure 1 shows the diffractograms of six samples from the three above-mentioned Provinces.

For the study of the pozzolanic activity of a material, numerous methods have been developed; these afford evaluations based on the observation of different properties of the samples (5).

Evaluation of the pozzolanic activity of the opaline rocks studied in the present work was carried out by tests on the material using calcium hydroxide.

The first test consisted in an accelerated activity test of strength; this was carried out on mortar specimens of the material plus lime (6) and allowed us to check the capacity of opaline rocks for use as pozzolans and to establish a classification among the samples (2).

The chemical test afforded data on the material-calcium hydroxide reaction rate; this proved to be similar to that of other products with known pozzolanic characteristics. 

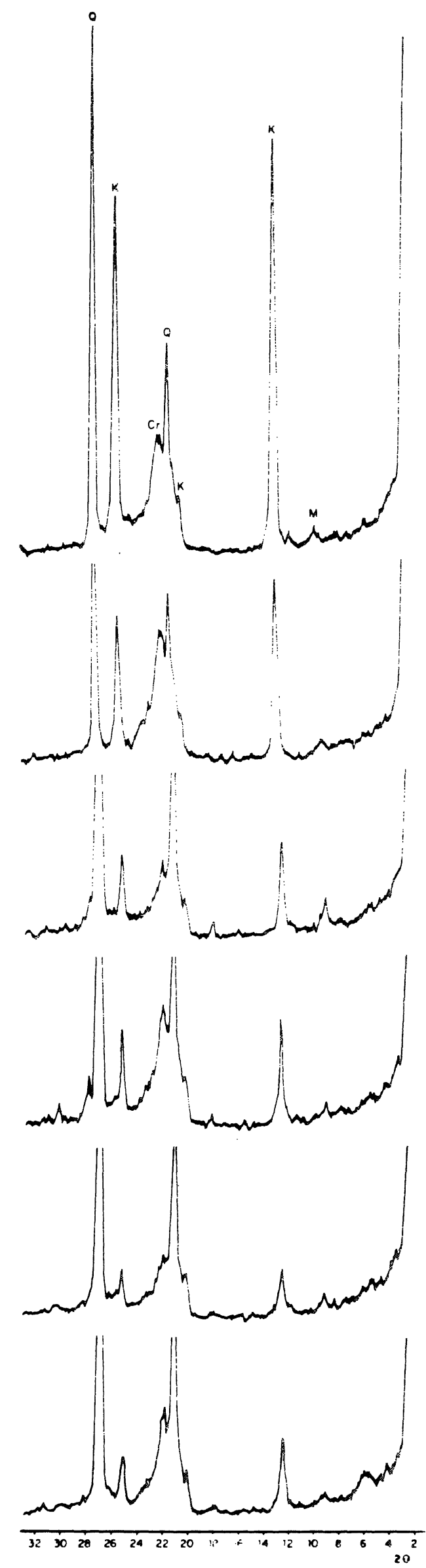

Fig. 1.-Difracción de rayos $\mathrm{X}$ de las rocas opalinas.

Fig. 1.-X-ray diffraction of the opaline rocks. 
También se aplicó un ensayo electroquímico, que en pocos minutos valora la actividad puzolánica de una muestra (7), y cuyos resultados ratificaron los anteriormente mencionados.

Seguidamente, y verificada la actividad puzolánica de las rocas opalinas se prepararon con ellas cementos mixtos, cuyas propiedades se detallan en este trabajo. Antecedentes de este estudio se encuentran en las "Jornadas en español y portugués sobre estructuras y materiales" (COLLOQUIA 88) (8), donde se presentaron parcialmente algunos de los resultados.

\section{CEMENTOS FABRICADOS CON MEZCLAS DE CEMENTO PORTLAND Y ROCAS OPALINAS}

Con este estudio se verifica la influencia de la incorporación de las rocas opalinas al cemento portland.

Los materiales escogidos son:

* Cemento Portland: Constituido exclusivamente por clinker portland y regulador de fraguado.

Las propiedades de este cemento tomado como base se estudian conjuntamente con los cementos mixtos fabricados.

* Rocas opalinas: Los materiales silíceos se han seleccionado entre las diferentes zonas geográficas.

Muestras 1, 2 y 3 Salamanca Muestras 4 y $5 \ldots . . \ldots \ldots \ldots$ Zamora Muestra $6 \ldots \ldots \ldots \ldots \ldots \ldots$ Avila

Los valores obtenidos para la densidad real y la superficie específica hallada mediante el permeabilímetro Blaine, como expresión de la finura de las muestras, por su influencia en el comportamiento de los cementos mixtos preparados posteriormente, se exponen en la Tabla I para las muestras de rocas opalinas, así como para el cemento portland base.

Con cada una de las seis rocas opalinas y el cemento portland base se han preparado tres mezclas, con porcentajes de cemento base del 80,70 y $60 \%$ en peso.

La elección de estos porcentajes en la elaboración de los cementos mixtos se debe a la consideración de los cementos con adición de puzolanas que se fabrican en la actualidad industrialmente.
An electrochemical test was also performed; in few minutes this evaluates the pozzolanic activity of a sample (7) and its results ratified those obtained with the other procedures.

Following this and after verifying the pozzolanic activity of the opaline rock, these were used to prepare mixed cements, whose properties are detailed in the present paper. Background information concerning this study can be found in "Jornadas en español and portugués sobre estructuras y materiales" (COLLOQUIA 88) (8) where part of the results were presented.

\section{CEMENTS MANUFACTURED WITH MIXES OF PORTLAND CEMENT AND OPALINE ROCKS}

The influence of the incorporation of opaline rocks to the portland cement is verified by this study.

The selected materials are:

* Portland Cement: It is only constitued by portland clinker and set regulator.

The properties of this base cement have been studied at the same time that the mixed cements manufactured.

* Opaline rocks: The siliceous materials have been selected from among the different geographic zones.

Samples 1, 2 y 3

Salamanca Samples 4 y $5 \ldots . \ldots \ldots \ldots \ldots \ldots$ Zamora Sample $6 \ldots \ldots \ldots \ldots \ldots$ Avila

The values obtained for the real density and the specific surface by the Blaine permeabilimeter, as a expression of the fineness of the samples, due to its influence on the behaviour of the mixed cements prepared subsequently, are exposed in the Table I for the samples of the opaline rocks, and the portland cement base.

Three mixes have been prepared with each of the six opaline rocks and the portland cement base, with percentages of the portland cement base of the 80,70 and $60 \%$ weight.

The choice of the percentages in the elaboration of mixed cements is due to the consideration of the cements with addition of pozzolans currently being manufactures industrially. 
TABLA I (TABLE I)

Densidad real y superficie especifica Blaine de las rocas opalinas y el cemento portland base

(Real density and Blaine specific surface of the opaline rocks and portland cement base)

\begin{tabular}{|c|c|c|}
\hline $\begin{array}{c}\text { ROCA OPALINA } \\
\text { OPALINE ROCK } \\
\mathbf{( N .}^{\circ} \text { ) }\end{array}$ & $\begin{array}{c}\text { DENSIDAD } \\
\text { DENSITY } \\
\left(\mathbf{g} / \mathbf{c m}^{3}\right)\end{array}$ & $\begin{array}{c}\text { SUPERFICIE ESPECIFICA } \\
\text { SPECIFIC SURFACE } \\
\left.\text { (u. Blaine; } \mathbf{c m}^{2} / \mathbf{g}\right)\end{array}$ \\
\hline 1 & 2,40 & 4.847 \\
2 & 2,51 & 4.981 \\
3 & 2,40 & 4.253 \\
4 & 2,50 & 5.171 \\
5 & 2,40 & 4.649 \\
6 & 2,44 & 4.742 \\
\hline
\end{tabular}

Para la realización de las mezclas se utilizó un mezclador de polvo de alta velocidad, que garantiza la perfecta homogeneización de los materiales tratados sin perturbar su granulometría.

Es de destacar, que estas rocas aunque son materiales que presentan tonalidades claras no tienen una influencia apreciable en cuanto al color de los cementos mixtos preparados. Sin embargo, al ser posible el seleccionar zonas en los yacimientos donde los materiales poseen color blanco, sería factible la preparación de cementos blancos con carácter puzolánico.

\section{PROPIEDADES DE LOS CEMENTOS FABRICADOS}

\subsection{Ensayo mecánico resistente}

La influencia de los materiales siliceos sobre el desarrollo mecánico de los cementos con adición a lo largo del tiempo, se verifica mediante un ensayo mecánico-resistente sobre probetas de morteros realizadas con arreglo a la norma UNE 80101 (9), hasta la edad de 2 años.

Los valores obtenidos en la resistencia a flexotracción (en $\mathrm{MPa}$ ), se exponen no como valores absolutos sino como las diferencias de los resultados correspondientes entre las edades de 7 y 720 días, para hacer más patente el efecto de la adición de roca opalina.

En la figura 2 quedan reflejados la totalidad de los cementos mixtos según los porcentajes de cemento base en las mezclas, incluido éste, y señalando cada uno de los seis materiales silíceos empleados en la preparación de los cementos con adición.
To perform the mixtures a high speed power mixer was used, this guarantees a perfect homogenization of the materials treated without disturbing granulometry.

It should be noted that althought these rocks are materials which had more or less light hues, the prepared mixed cements were not appreciably different in colour from the base portland cement. However, it is possible to chose the zones of the terrains where the materials had white colour, it will be possible the manufacturation of the white cements with pozzolanic properties.

\section{PROPERTIES OF THE MANUFACTURED CEMENTS}

\subsection{Mechanical strength test}

The influence of the siliceous materials on the stregth development of the cements with addition over time is verified by a mechanicalstrength test with mortar specimens prepared according to the UNE 80101 standard (9), up to the age of 2 years.

The values obtained in the flexural strength (in $\mathrm{MPa}$ ) are expressed not as absolute values but rather as the differences in the results between ages of 7 and 720 days to highlight the effect of the added opaline rock.

In the figure 2 the whole of mixed cements are presented, according to the proportion of the base cement in the mixtures, and each of the six siliceous materials used in the preparation of the cements with addition and the base cement are signed. 


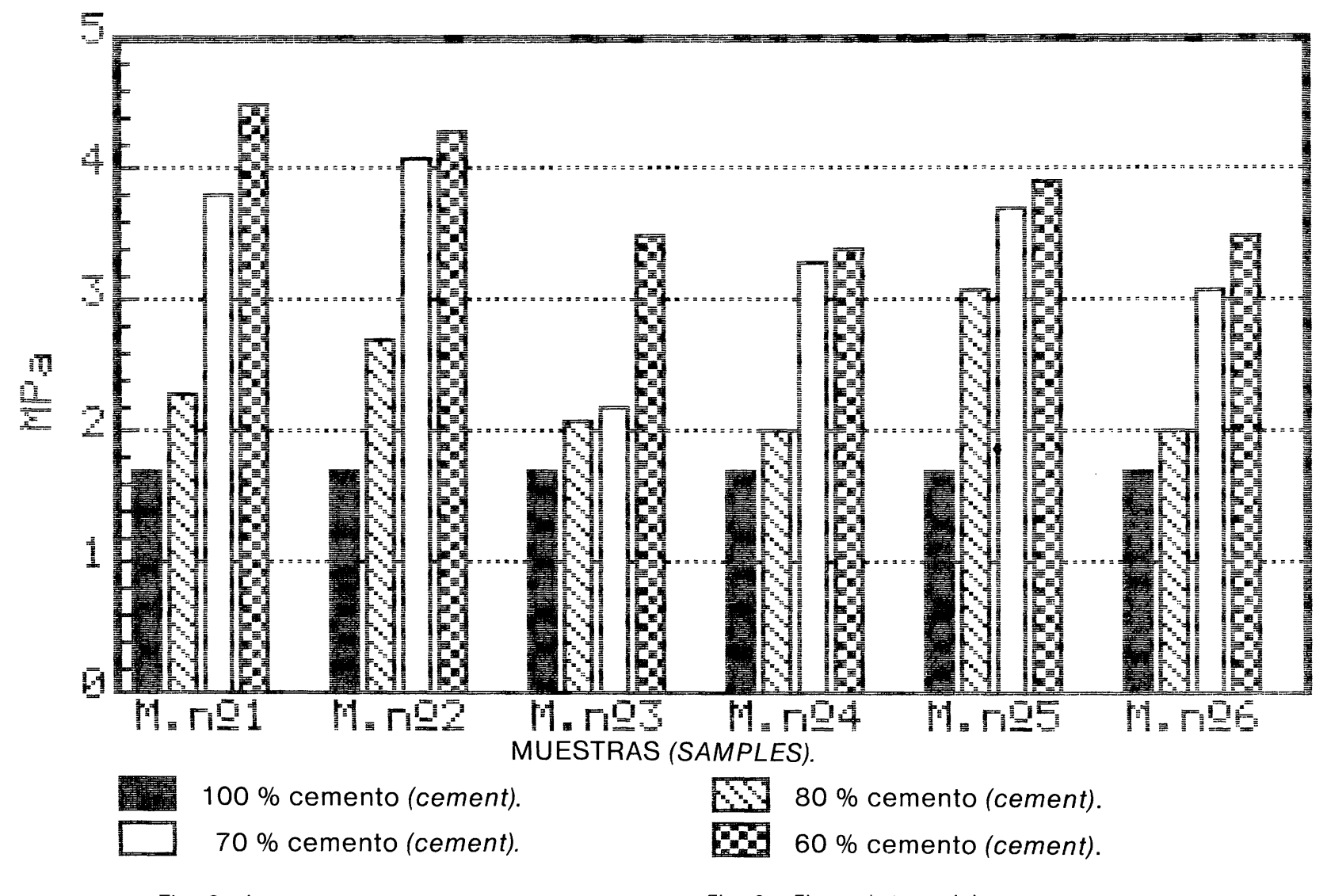

Fig. 2.-Incremento resistencia flexotracción.

Fig. 2.-Flexural strength increase.

La resistencia a compresión (en MPa), se representa por separado para cada una de las muestras, según las distintas edades, y para todos los porcentajes de cemento, incluido el cemento portland base.

Las figuras $3,4,5,6,7$ y 8, corresponden respectivamente a las muestras $1,2,3,4,5$ y 6 , recogiendo valores hasta 720 días $(7,28$, $90,180,360$ y 720 dias).

En la figura 9, aparecen tres curvas que corresponden a cada uno de los porcentajes de cemento utilizado en la fabricación de los cementos mixtos. Para cada edad el valor representado en la curva es la media de las seis medidas obtenidas con cada una de las seis muestras de ópalos a una misma proporción de mezcla.

En esta representación, se observa un máximo a la edad de 28 días en las tres curvas. La razón se debe a las características de la reacción con la cal de las rocas opalinas. ESTOS MATERIALES PRESENTAN UNA REACTIVIDAD MUY ELEVADA A LAS PRIMERAS EDADES y alcanzan pronto sus cotas máximas.
The compressive strength (in $\mathrm{MPa}$ ) is represented for every sample at the different ages and for every proportion of cement, base cement included.

The figures 3, 4, 5, 6, 7 and 8 , are in relation to the samples 1, 2, 3, 4, 5 and 6 respectively, where values up to 720 days are showing (7, 28, 90, 180, 360 and 720 days).

Three curves are presented in the figure 9, which correspond to every percentages of used cement for mixed cements manufacturation. For each age the value represented in the curve is the mean value of the six measurements obtained with each of the six opal samples for the same proportion mix.

In this figure a maximum is observed for the three curves at 28 days. This is because of the characteristics of the reaction with lime of the opaline rocks. THESE MATERIALS HAVE A VERY HIGH REACTIVITY DURING THE EARLY AGES and soon reach maximum values. 
LAS CONSECUENCIAS que se desprenden de estos ensayos mecánicos-resistentes son:

* La incorporación de rocas opalinas no aumenta el requerimiento de agua en el amasado de los cementos mixtos preparados.

* La adición de material silíceo provoca un aumento en la resistencia a flexotracción de los cementos con respecto al cemento portland utilizado como base (Fig. 2). Este incremento es tanto mayor cuanto más elevada es la proporción de roca opalina. Con respecto al tiempo, el cemento portland mantiene prácticamente constante el valor de resistencia a flexotracción, mientras que los cementos mixtos presentan un incremento mayor de este valor.

* La resistencia a compresión alcanzada por los cementos con adición de rocas opalinas preparados, se encuentra por debajo del valor correspondiente al cemento base para cada edad.
THE CONSEQUENCES of these mechanicalstrength tests are:

* The incorporation of the opaline rocks does not increase the water requirement for the mass in the mixed cements prepared.

* The addition of the siliceous material provokes an increase in the flexural strength of the cements in relation to the portland cement used as base (Fig. 2). This increase becomes greater as the proportion of opaline rock increases. Regarding time, portland cement maintains practically constant the value of the flexural strength whereas the mixed cements show a greater increase in this value.

* The compressive strength of the cements prepared with addition of the opaline rocks is below the value corresponding to the reference portland cement for each age.

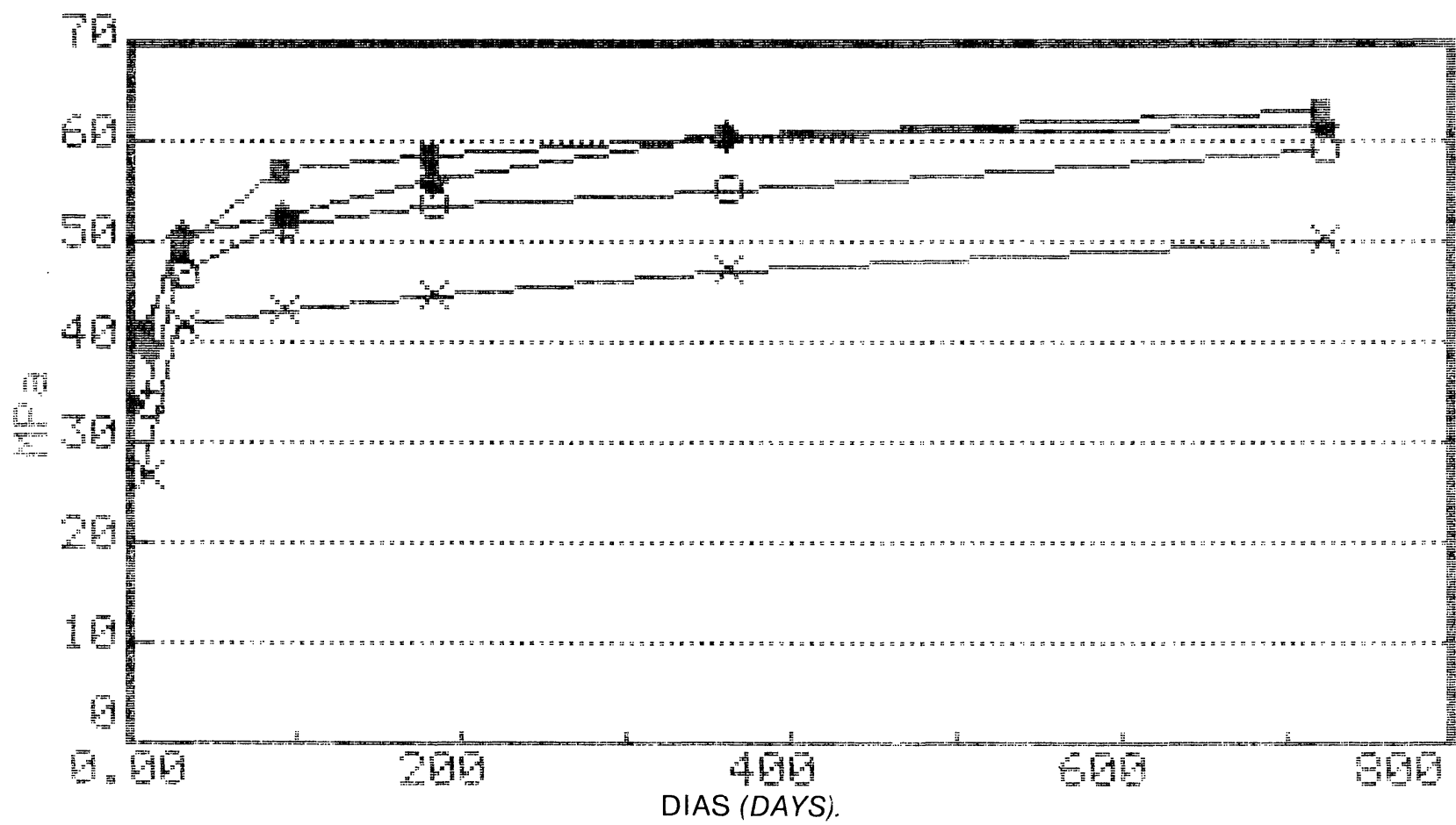

萿 $100 \%$ cemento (cement).

I $70 \%$ cemento (cement).

Fig. 3.-Resistencia a compresión (Muestra N. ${ }^{\circ} 1$ ).
挛 $80 \%$ cemento (cement).

"nin $\quad 60 \%$ cemento (cement).

Fig. 3.-Compressive strength (Sample N. 1). 


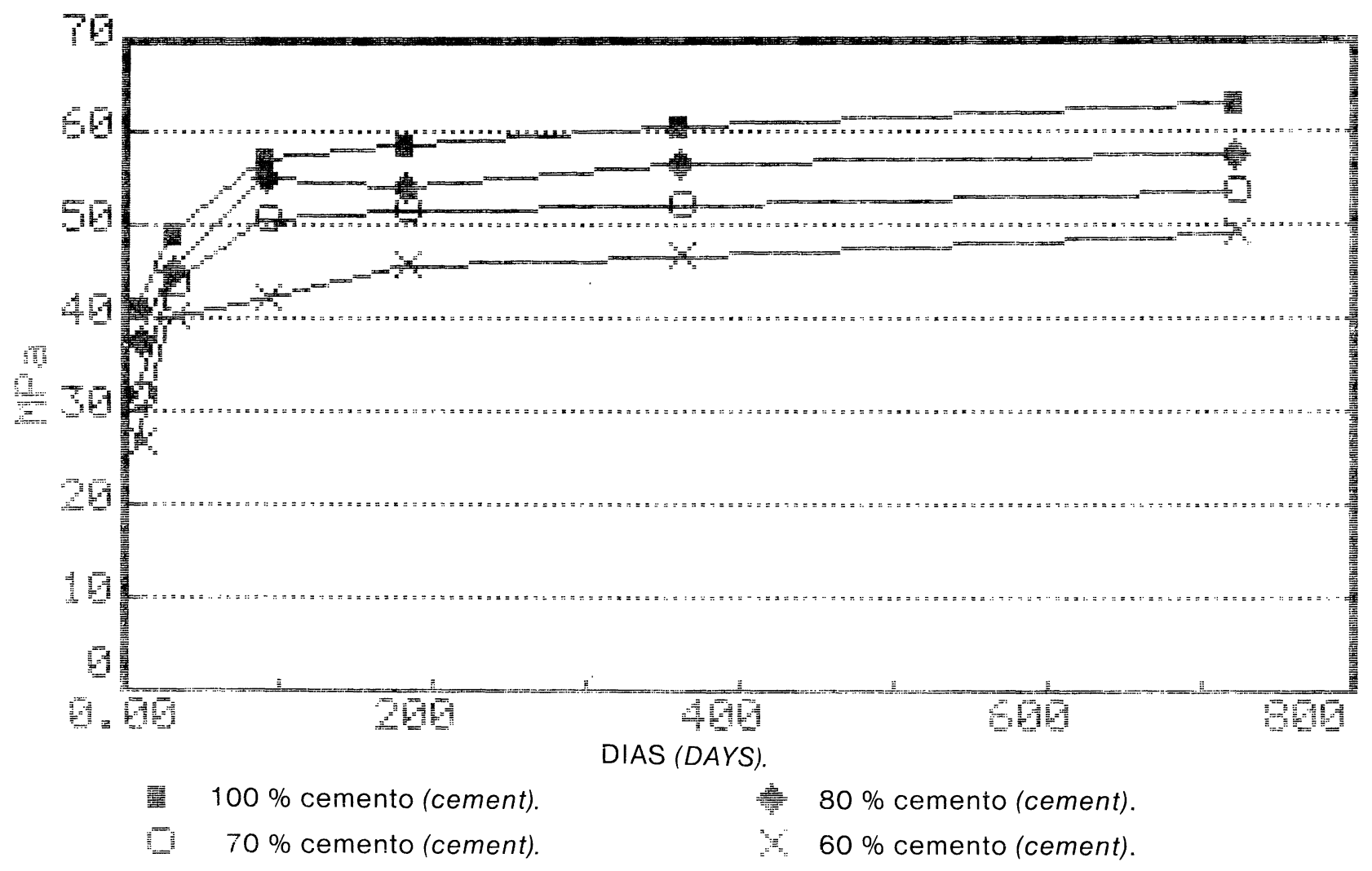

Fig. 4.-Resistencia a compresión (Muestra N. 2). Fig. 4.-Compressive strength (Sample N. 2).

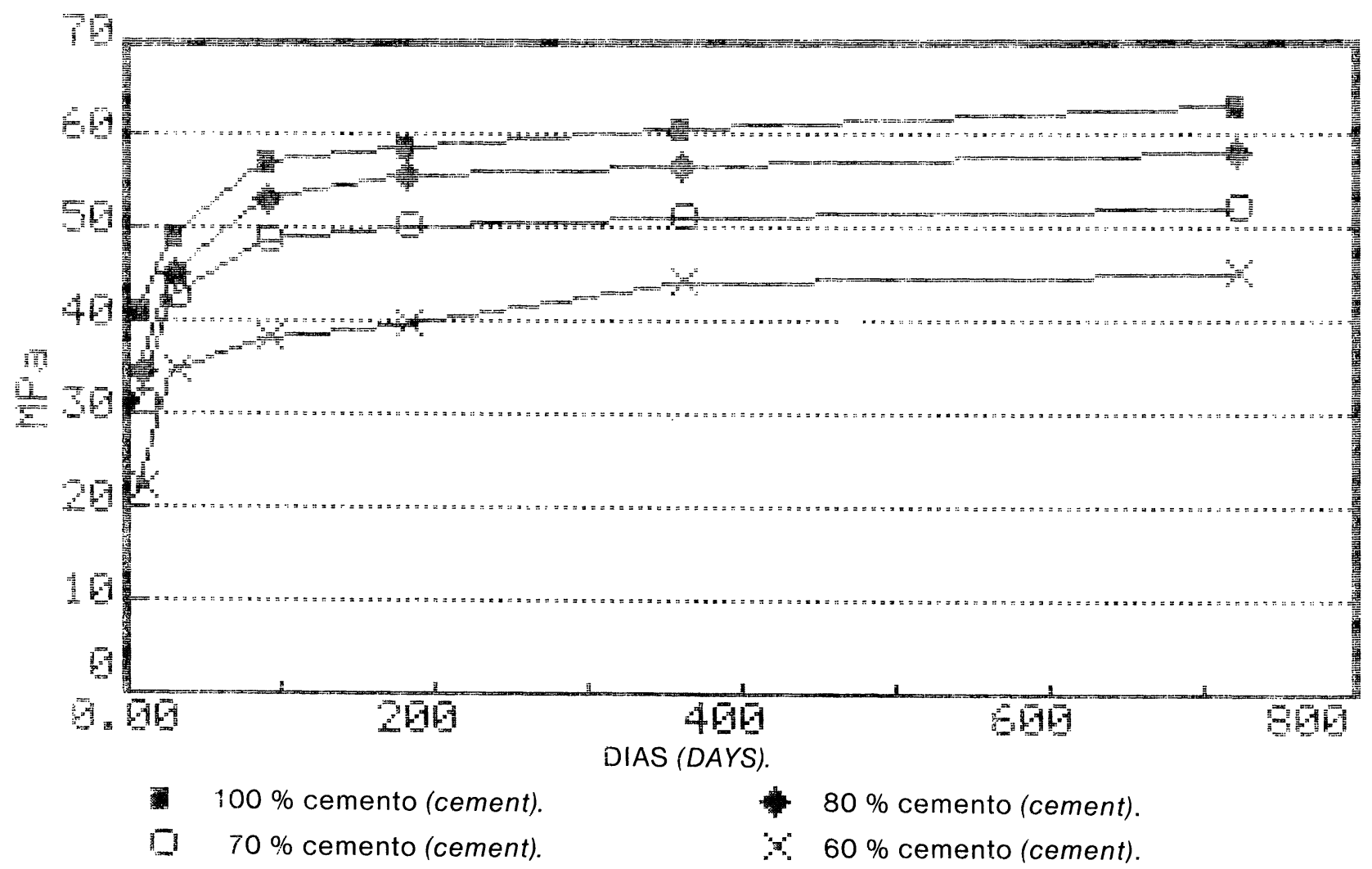

Fig. 5.-Resistencia a compresión (Muestra N." 3).

Fig. 5.-Compressive strength (Sample N. 3). 


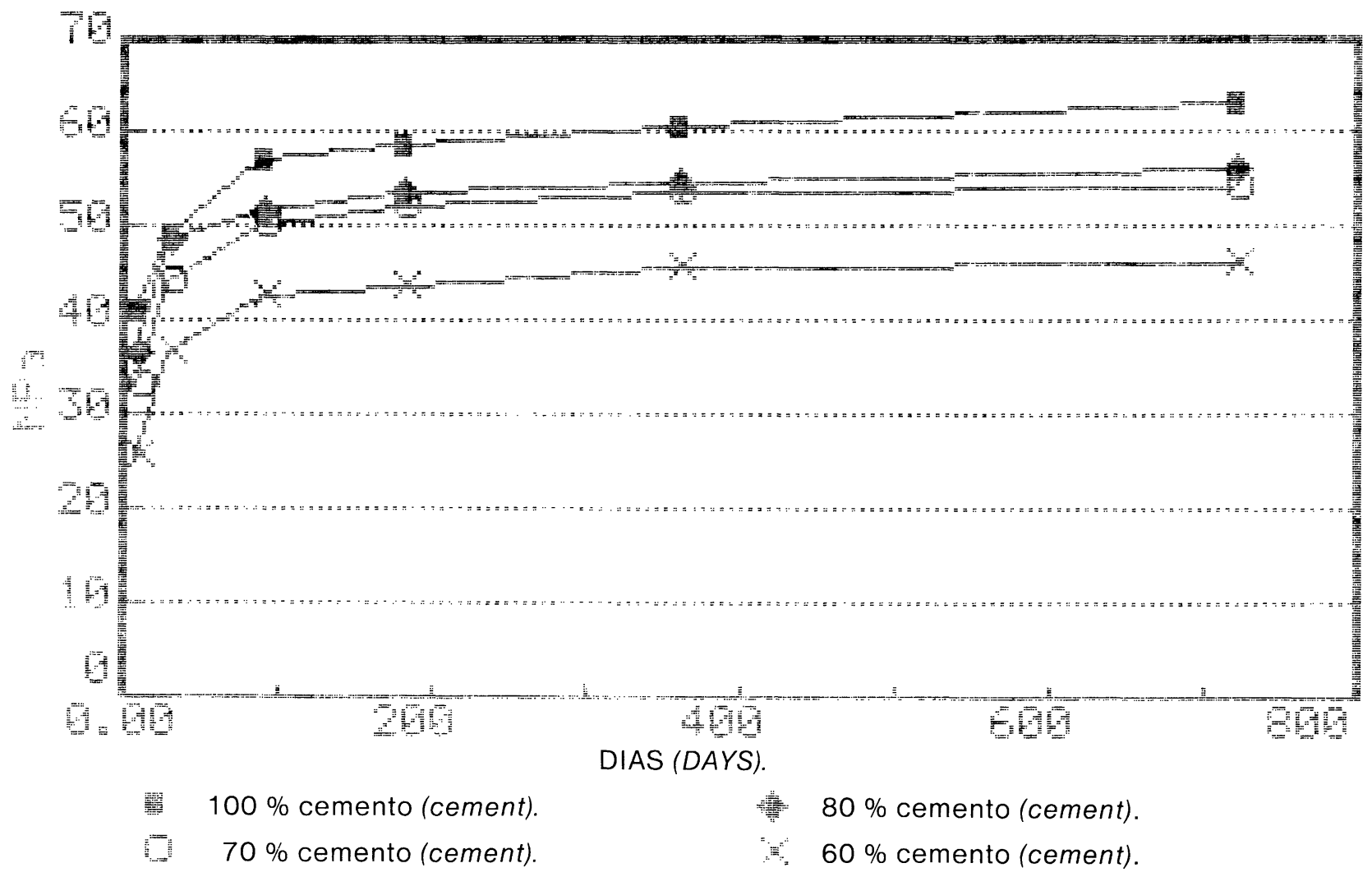

Fiq. 6.-Resistencia a compresión (Muestra N. 4).

Fig. 6.-Compressive strength (Sample N. 4).

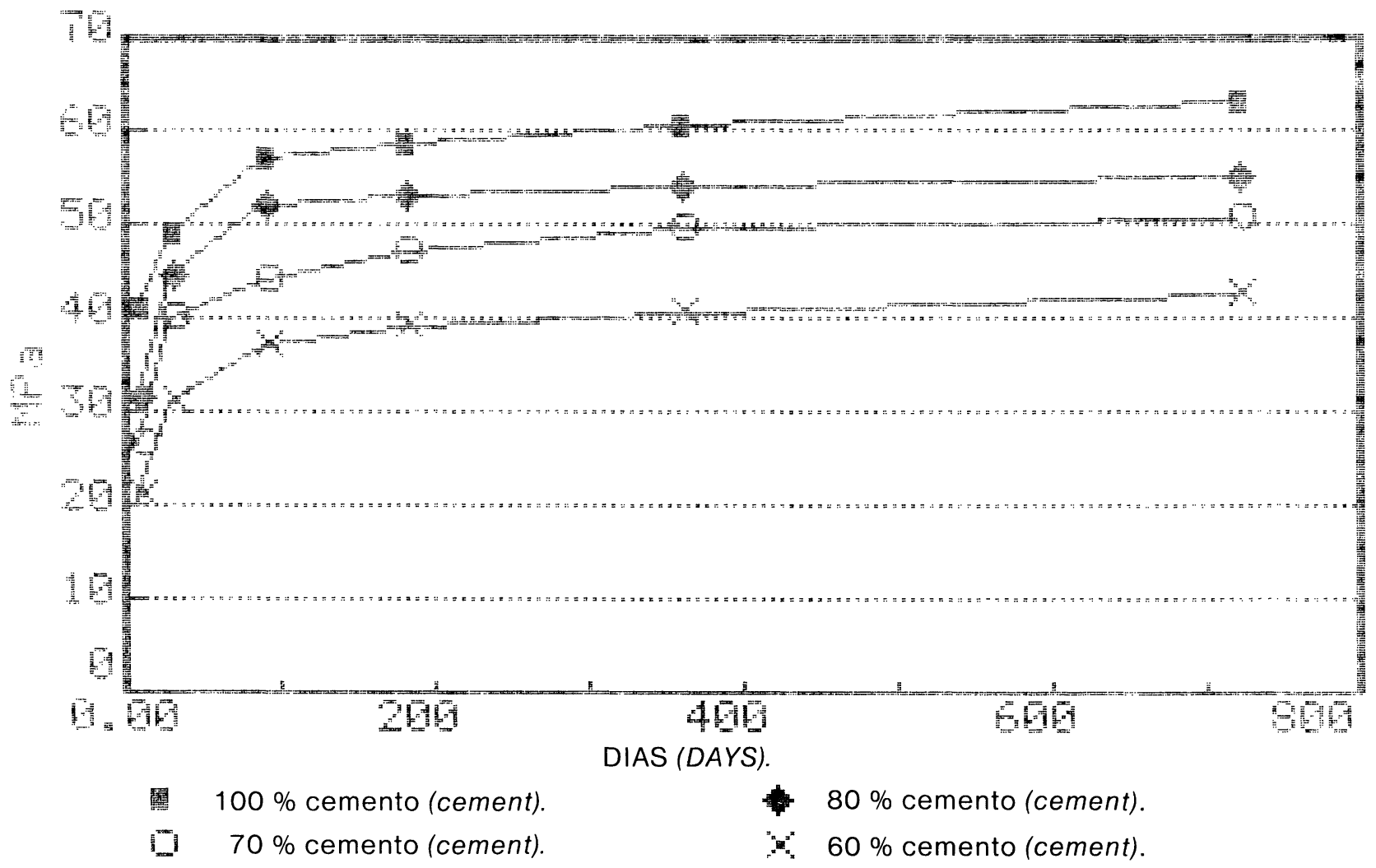

Fig. 7.-Resistencia a compresión (Muestra N. 5).

Fig. 7.-Compressive strength (Sample N. 5). 


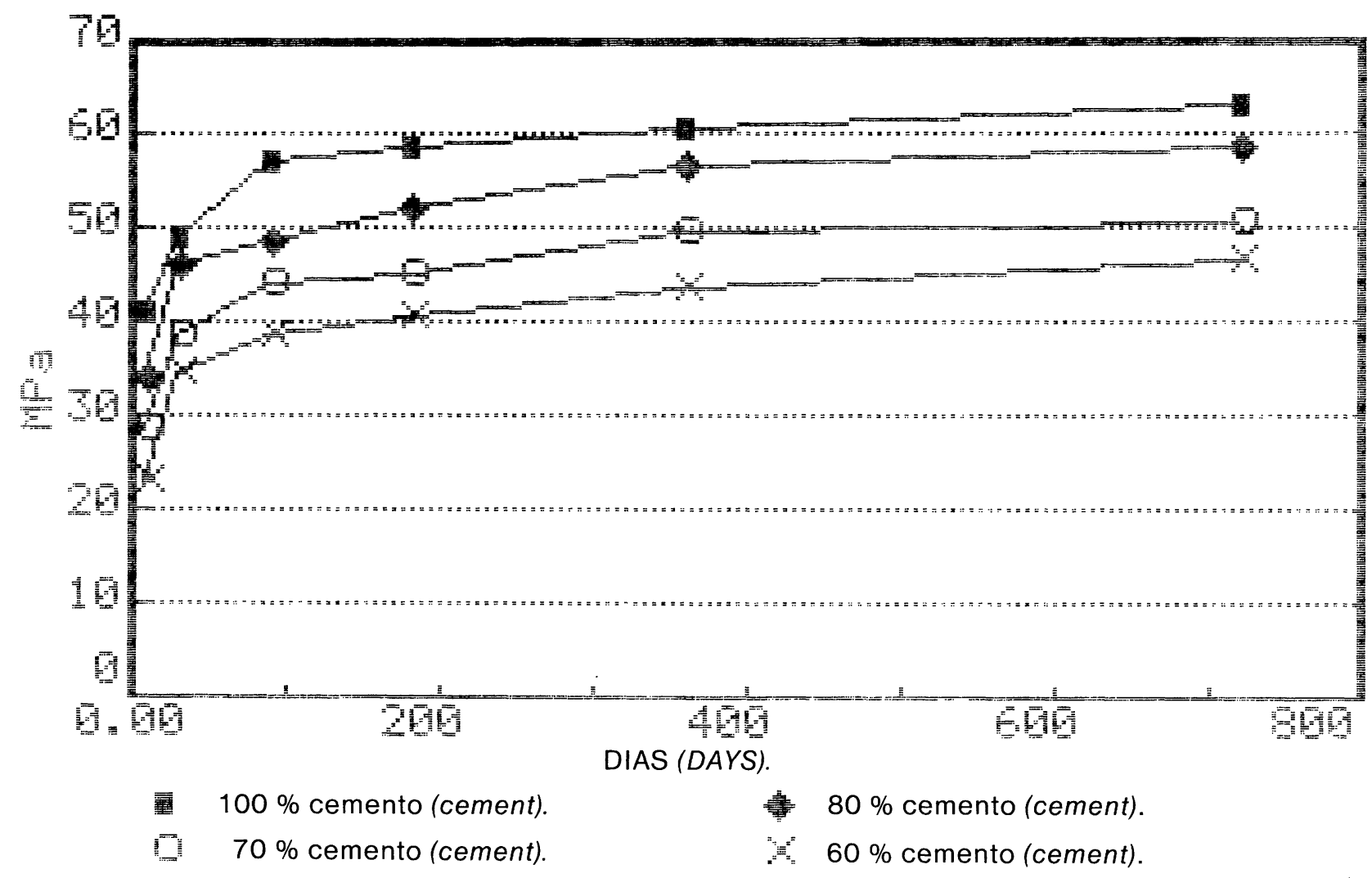

Fig. 8.-Resistencia a compresión (Muestra N." 6). Fig. 8.-Compressive strength (Sample N. 6).

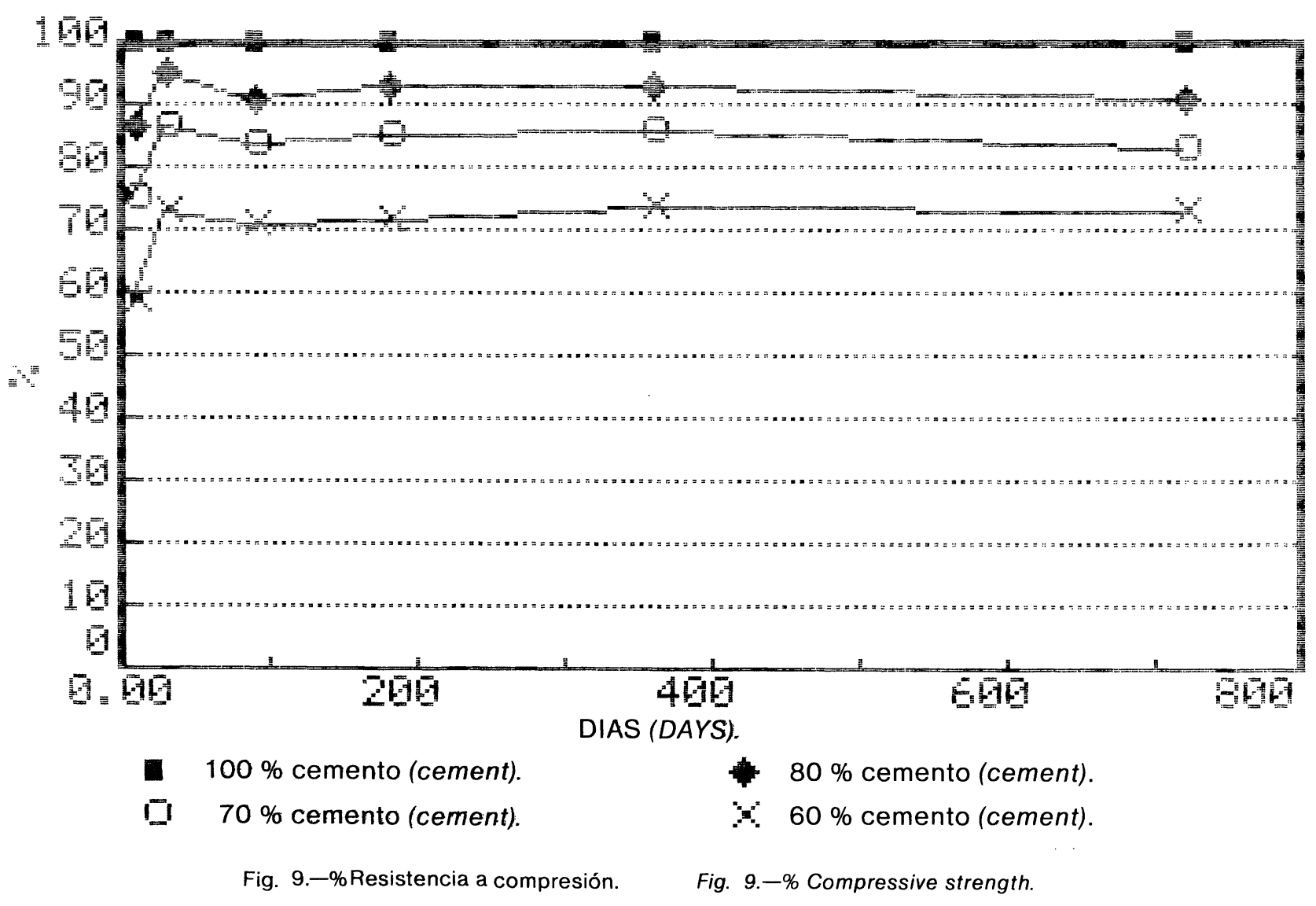




\subsection{Ensayo de puzolanicidad}

Este ensayo se describe en la norma UNE 80 280 (10) y corresponde también a la normalización europea. Se basa en la solubilidad del hidróxido cálcico en presencia de álcalis.

En la figura 10 se presentan los resultados obtenidos para cada una de las mezclas preparadas con el cemento portland y el material silíceo, así como los correspondientes al cemento base, expresados como índices puzolánicos positivos a las edades estudiadas (1, 2, 3, 7, 8, 15 y 28 días).

LA CONSECUENCIA que se deduce de este ensayo es que la actividad puzolánica de las rocas opalinas se pone de manifiesto al comprobar que ya a partir de 7 días el índice de puzolanicidad es positivo para todos los cementos mixtos con un porcentaje de roca del 30 y $40 \%$, cumpliéndose dicho ensayo incluso a 3 días en alguno de los casos.

\subsection{Pozzolanicity test}

This test of pozzolanicity applied is described in the UNE 80280 (10) and has been the object of attention of the european standards. It is based on the solubility of calcium hydroxide in the presence of alkalis.

Int the figure 10 the obtained results are showed for each of the mixtures prepared with the portland cement and the siliceous material, together with the corresponding results for the portland cement base; they are expressed as positive pozzolanic activity indices at ages studied (1, 2, 3, 7, 8, 15 and 28 days).

THE CONSEQUENCE of this test is that the opaline rocks have pozzolanic activity, it can be verified since from 7 days onwards the pozzolanic activity index is positive for each mixed cement with a percentage of addition of rock of 30 y $40 \%$, and even at 3 days in some cases.

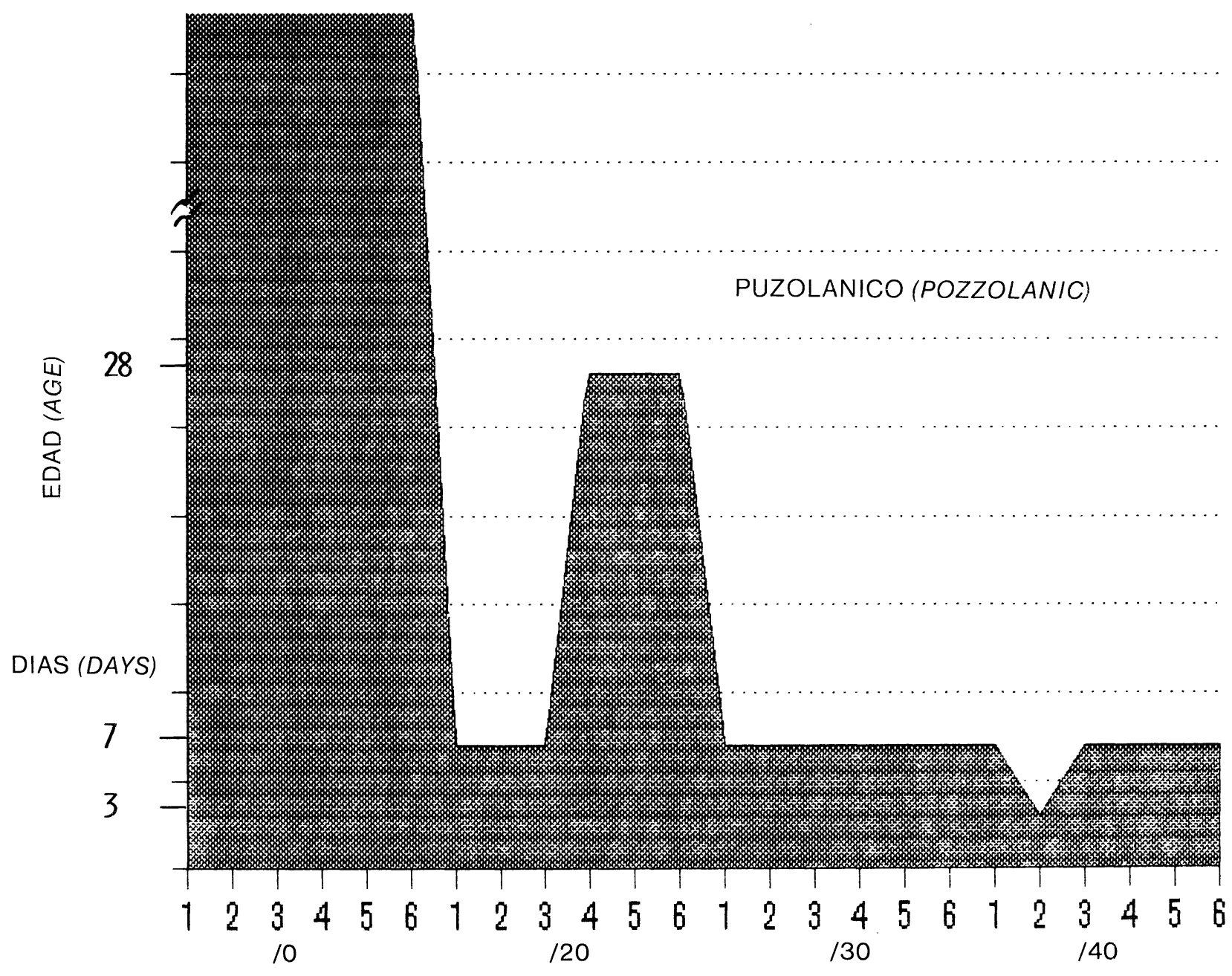

MUESTRA N. ${ }^{\circ}$ (SAMPLE N.): 1,2,3,4,5,6. PORCENTAJE (PERCENTAGE): 0,20,30,40.

Fig. 10.-Ensayo de puzolanicidad de los cementos mixtos preparados.

Fig. 10.-Pozzolanicity test of the mixed cements prepared. 
Para el porcentaje de adición del $20 \%$, un $50 \%$ de las muestras cumplen con el ensayo a 7 días y el resto lo hacen a 28 dias.

\subsection{Ensayo de estabilidad de volumen}

Este ensayo, realizado según el método de las agujas de le Châtelier, está descrito en la norma UNE 80102 (11).

Los valores obtenidos oscilan entre 0 y $1 \mathrm{~mm}$, lo que indica que estos materiales silíceos no xcasionan inestabilidad de volumen en los cementos con ellos fabricados.

LA CONSECUENCIA de estos resultados es que la presencia de rocas opalinas en el cemento con elevado grado de finura no es causa de expansiones, sino que su efecto sería el de inhibidor de las mismas.

\section{CONCLUSION}

En este trabajo se han presentado LAS CONSECUENCIAS para cada uno de los ensayos que se realizaron para caracterizar a los cementos preparados con rocas opalinas, como resumen de todas ellas se desprende que:

Las rocas opalinas pueden ser utilizadas como materiales puzolánicos.
For the percentage of addition of $20 \%$, the tests yielded positive results from an age of 7 days in the $50 \%$ of the cases, and the rest as from 28 days.

\subsection{Soundness test}

This test was realised according to the Le Chatelier method, this is described in the UNE 80102 standard (i1).

The values obtained ranged between 0 and $1 \mathrm{~mm}$, this shows that the siiiceous materials do not lead to unstability in volumen in the cements manufactured with them.

THE CONSEQUENCE of these resuits in that the presence of the opaline rocks finely grinded in the cement do not cause expansion.

\section{CONCLUSION}

In this paper THE CONSEQUENCES for each of the tests carried out in the characterization of the prepared cements with opaline rocks had been shown; and as an alone remark:

The opaline rocks can be used as pozzolanic materials.

\section{BIBLIOGRAFIA}

(1) BUCCHI, R. (1980): 7 th $^{\text {th }}$ Int. Congr. Chem. Cem., París, I, I-1/3-44.

(2) LUXAN, M. P. de; SANCHEZ DE ROJAS, N. I.; MARTIN PATINO, N. T.; SAAVEDRA, J. (1986): 8 . $^{\text {th }}$ Int. Congr. Chem. Cem., Rio de Janeiro, VI, 468-469.

(3) LUXAN, M. P. de; SANCHEZ DE ROJAS, M. I.; MARTIN PATINO, M. T.; SAAVEDRA, J. (1987): $1 .^{\text {st }}$ Int. RILEM Congress, París. Ed. Chapman and Hall. Pore structure and Materials Properties. I, 191-194.

(4) MARTIN PATINO, M. T.; SAAVEDRA, J. (1981): Cuad. Lab. Xeol. Laxe, 2, 253-261.

(5) SERSALE. R. (1980): $7 .^{\text {th }}$ Int. Congr. Chem. Cem., Paris, I, IV-1/3-21.

(6) LUXAN, M. P. de; SANCHEZ DE ROJAS, M. I. (1985): Materiales de Construcción (IccET), 200, 3-13.

(7) LUXAN, M. P. de; MADRUGA, F.; SAAVEDRA, J. (1989): Cem. and Concr. Research, $19,1$.

(8) LUXAN, M. P. de; SANCHEZ DE ROJAS, M. I.; MARTIN PATINO, M. T.; SAAVEDRA, J.; MADRUGA, F.; FRIAS, M. (1988): Jornadas en Español y Portugués sobre Estructuras y Materiales, COLLOQUIA, Madrid, I, 191-215.

(9) Norma UNE 80 101: Métodos de Ensayo de Cemento. Determinación de la Resistencia Mecánica.

(10) Norma UNE 80 280: Métodos de Ensayo de Cemento. Análisis Quimico. Puzolanicidad.

(11) Norma UNE 80 102: Métodos de Ensayo de Cemento. Ensayos Físicos. Determinación del tiempo de Fraguado y de la Estabilidad de Volumen. 